times arises as to whether the preparation is being sold as anhydrous radium bromide or radium bromide with its water of crystallisation.

The radio-active department in the Reichsanstalt has now been in operation for more than a year, under the charge of Dr. Geiger, whose radio-active researches in the University of Manchester are well known. The creation of this department has been found to fill a much-needed want, and it is not too much to say that practically all the radium and mesothorium that is bought and sold in Germany requires to-day the certificate of the Reichsanstalt. The number of standardisations required have increased very rapidly, and several assistants have been added to the department in charge of this work alone. There can be no doubt that the institution of a radio-active department in the National Physical Laboratory will prove of great service to this country, not only for scientific, but also for commercial purposes. It is well known that the buying and selling of radium in the past has been a very uncertain and risky procedure, for in most cases the radium content has not been expressed in terms of any authorised standard. This difficulty is removed by the present arrangement, and we should strongly recommend that those who wish to buy radium or mesothorium, whether for scientific or for medical purposes, should do so conditional on the certificate of standardisation from the National Physical Laboratory.

It is understood that the work of testing and standardisation will be under the supervision of Dr. W. G. C. Kaye, of the National Physical Laboratory, whose pioneer work on the production and distribution of X-rays is well known to all physicists. The ability and skill in measurements which he has shown both in his work in the Cavendish Laboratory and in the National Physical Laboratory, afford the best of guarantees that the work of the new department will be carried out in a thoroughly satisfactory manner.

E. Rutherford.

\section{SIR ROBERT BALL, F.R.S.}

ROBERT STAWELL BALL was born in Dublin on July $\mathrm{I}$, I840, the eldest son of Dr. Robert Ball, director of the Natural History Museum in the University of Dublin and secretary of the Queen's University in Ireland. After attending school at Abbott's Grange, Chester, he entered Trinity College, Dublin, in $1857 . \mathrm{He}$ became a mathematical scholar in I860, Lloyd exhibitioner the same year, and graduated in I86I as gold medallist in mathematics, first gold medallist in experimental and natural sciences and University student in mathematics. Towards the end of $x_{86}$ he went to Parsonstown as tutor to the three younger sons of the third Earl of Rosse and observer with the great sixfoot and three-foot telescopes. When Ball began to use the six-foot reflector in February, 1866 , nearly all the larger and more interesting nebulæ had been frequently observed and carefully drawn, and he therefore chiefly devoted himself to work with the micrometer, a difficult task, since the telescope at that time had not yet been provided with a clock motion. He was the first observer with the instrument who corrected the measured position angles for the error due to the telescope not being equatorially mounted, but supported at the lower end on a universal joint. His observations were included in the "Observations of Nebulæ, I848-78," published by the late Lord Rosse in $1879-80$.

In the autumn of 1867 , shortly before the death of the maker of the great telescope, Ball was appointed professor of applied mathematics and mechanism at the newly established Royal College of Science for Ireland, in Dublin. He was singularly well fitted for this post, as he was not only an excellent mathematician and had the power of elucidating even abstruse subjects in simple and clear language, but also possessed great skill in experimental work. In addition to his regular class work, he also sometimes gave evening lectures on mechanics in a more elementary form, and in $187 \mathrm{I}$ he published his first popular book, "Experimental Mechanics," which was very well received and showed his great aptitude both as a popular lecturer and as a writer. It led to his being much sought after as a lecturer; and as lectures on mechanics required a large amount of apparatus, he preferred to lecture on popular astronomy, and by degrees he became the most successful lecturer on this subject, not only in this country, but in after years also in America.

In January, 1870 , Ball read a paper before the Royal Irish Academy on the small oscillations of a rigid body about a fixed point under the action of any forces. Out of this investigation grew the long series of memoirs which he published on the theory of screws in the course of the next thirty-four years, nearly all in the Trans. Roy. Irish Academy. This remarkable extension of theoretical dynamics, perhaps the most important contribution to that science since the introduction of couples by Poinsot, combines Poinsot's force and couple into the single conception of a wrench on a screw, the latter being regarded merely as "a directed straight line with an associated linear magnitude called the pitch." The capabilities of the theory were gradually shown to be very great, as all the results of modern algebra and geometry appear to be applicable to it. Ball published a separate book on the subject in 1876 , and in I889 Dr. Gravelius wrote a text-book in German, founded on Ball's first eight memoirs. Finally, Ball's great "Treatise on the Theory of Screws" appeared at Cambridge in 1900 , but even after that date several succeeding memoirs showed that the author of the theory continued to devote his mind to its extension.

The growing fame of Ball as a mathematician and the warm interest he was kirown to take in astronomy naturally led the Board of Trinity College to appoint him to the Andrews professorship of astronomy in the University of Dublin, 
when it became vacant in 1874 . Ball threw himself into his new duties at Dunsink Observatory with his usual energy, and decided to continue the investigations on the annual parallax of stars carried out by his predecessor, Brünnow, by means of micrometer observations. In addition to working on a few stars throughout the year in the usual way, he broke fresh ground by attempting to find stars with a large parallax by what he called "reconnoitring observations." $\mathrm{He}$ observed a great number of stars only twice, with an interval of six months, at the time of greatest parallactic displacement. In a very few cases the measures seemed to indicate that the star might be within a measurable distance from us, and he therefore took a regular series of observations of these stars. For two stars he found in this way parallaxes of a third of a second and half a second, which, however, were not subsequently confirmed, and the rapid rise of astronomical photography has led to the complete abandonment of visual observations in work on annual parallax. But Ball's experiment in search of stars with a large parallax is an in teresting one all the same. For three or four years he deroted his whole time to this work, which he arranged and carried out in the most businesslike and methodical manner, often observing till 2 or 3 o'clock in the morning, and the results were published in Parts III. and V. of the Dunsink Observations, the latter of which appeared in 1884 . After that time he seems to have done very little observing, probably on account of renewed trouble with one of his eyes, which had been accidentally injured in his youth, and later (in 1897 ) had to be removed.

In 1884 Ball was appointed scientific adviser to the Commissioners of Irish Lights, and in I886 he was knighted by the Lord Lieutenant of Ireland. In February, I892, he was elected Lowndean professor of astronomy and geometry and director of the Observatory at Cambridge, leaving Dunsink to take up the appointment in the following autumn. At Cambridge he continued as previously to divide his time between his official duties, his mathematical researches, and his activity as a popular lecturer and writer of popular astronomical books and articles. $\mathrm{He}$ was president of the Royal Astronomical Society in $1897-99$. In 1908 he published his last book, "A Treatise on Spherical Astronomy," more intended for the use of college students than for practical astronomers, but written in his usual clear and concise style.

Sir Robert Ball died on November 25, after a long and lingering illness. His genial and hearty manner, his fund of wit and his enthusiasm for any subject which had taken hold of his mind, made him a favourite wherever he went. Anyone who has worked under him will not forget his readiness to allow his subordinates to carry out any special work in their own way and to reap therefrom whatever credit they could.

J. L. E. D.
THE ANNIVERSARY MEETING OF THE ROYAL SOCIETY.

THE anniversary meeting of the Royal Society was held on Monday, December I, when the report of the Council was presented and the retiring president, Sir Archibald Geikie, delivered an address. Sir William Crookes was elected president of the society, and the other officers and members of council, whose names were given in NATURE of November 13 (p. 324), were also elected.

The council reports that a critical period has been reached in the development of the work of the committee on the Catalogue of Scientific Papers. Since $190 \mathrm{I}$ the sum of $2 \mathrm{I}, \mathrm{I}_{5} \mathrm{I} l$. I5s. $2 d$., mainly contributed by the late Dr. Ludwig Mond, has been expended on the preparation of the Catalogue, and with the exception of the income of the Handley Fund, now amounting to about I $90 l$. a year, there are no funds available for continuing the work after the end of this year.

The whole of the tenth annual issue of the International Catalogue of Scientific Literature has been published, with the exception of the volumes of physiology and bacteriology. A meeting of the International Council will be held in 19I4. At this meeting the question of continuing the Catalogue beyond the first fifteen issues will be taken into consideration.

In the course of the year the treasurer received from the executors of the late Lord Lister, securities and cash to the value of $8995 l$. 9s. rod., on account of a legacy left by Lord Lister to the society for its general purposes.

The financial position of the National Physical Laboratory has been a cause of anxiety to the Council. In consequence mainly of the strikes and general disturbance of trade at the beginning of 1912, the receipts for the year were less than the expenditure, and but for a considerable revival at the end of the year would have been much less. The responsibility for any deficit rests with the society; and the council, while ready to advance by all means in its power the national work of the Laboratory, considers that the society should be freed from this serious liability. It is in communication with the Treasury on the question. Much valuable work is at a standstill for want of funds.

In his presidential address, Sir Archibald Geikie referred to some of the subjects in the report presented by the council, and particularly to the national activities of the society and the inadequacy of the financial provision necessary for the carrying out of important work. He pointed out that five years ago at the request of the Home Office the council appointed a committee to investigate the physical and physiological problems presented by the disease known as glassworkers' cataract. In proposing this inquiry, the Home Office made no provision for the cost of the numerous experiments and examinations that obviously would be required, while the Royal Society has no funds at its disposal for meeting

NO. 23OI, VOL. 92] 